\title{
POLA INTERAKSI VIRTUAL AKUN INSTAGRAM @WARGANETBERSABDA TENTANG PERUNDUNGAN SIBER
}

\author{
Aulia Risyda Fauzi ${ }^{1}$, Lucy Pujasari Supratman ${ }^{2}$ \\ ${ }^{1,2}$ Fakultas Komunikasi dan Bisnis, Program Studi Ilmu Komunikasi, Universitas Telkom \\ Jl. Telekomunikasi - Ters. Buah Batu, Bandung, 40257, Indonesia \\ No. Telp./HP: ${ }^{1} 08285318846697,{ }^{2} 081221524351$ \\ E-mail: ${ }^{1}$ aull.risyda@gmail.com, ${ }^{2}$ doktorlucysupratman@gmail.com
}

Naskah diterima tanggal 14 Januari 2019, direvisi tanggal 26 Maret 2019, disetujui tanggal 15 April 2019

\section{VIRTUAL INTERACTION PATTERN AT INSTAGRAM ACCOUNT @WARGANETBERSABDA ABOUT CYBERBULLYING}

\begin{abstract}
The @warganetbersabda is the first Instagram account in Indonesia, which is vigorously fighting against cyberbullying on social media and is managed directly by an influencer, Gita Savitri. The purpose of this research is to explain how the virtual interaction pattern of Instagram account @warganetbersabda about cyberbullying occurs. By knowing the patterns of virtual interaction, digital societies can learn how these patterns work in a digital phenomenon so that digital societies can adapt these patterns to manage and develop movements that are being managed on social media. This research uses a virtual ethnographic approach. The result of this research is the virtual interaction pattern of Instagram account @ warganetbersabda that experiences a convergence in which the convergence between admin and followers and among other followers in the Instagram account @warganetbersabda create a collective awareness of cyberbullying on social media.
\end{abstract}

Keywords: virtual ethnography, Instagram, cyberbullying.

\begin{abstract}
Abstrak. Akun @warganetbersabda merupakan akun Instagram pertama di Indonesia yang gencar melakukan perlawanan mengenai perundungan siber di media sosial dan dikelola langsung oleh seorang influencer, Gita Savitri. Penelitian ini hendak menjelaskan bagaimana pola interaksi virtual akun Instagram @warganetbersabda tentang perundungan siber terjadi. Dengan mengetahui pola interaksi virtual, masyarakat digital dapat mempelajari bagaimana pola ini bekerja dalam suatu fenomena digital sehingga masyarakat digital dapat mengadaptasi pola tersebut untuk mengelola dan mengembangkan gerakan yang sedang dikelola di media sosial. Penelitian ini menggunakan pendekatan etnografi virtual. Hasil dari penelitian ini adalah pola interaksi virtual akun Instagram @ warganetbersabda mengalami sebuah konvergensi yang mana konvergensi antara admin dengan pengikut dan antar pengikut lainnya dalam akun Instagram @warganetbersabda membentuk sebuah kesadaran kolektif mengenai perundungan siber di media sosial.
\end{abstract}

Kata kunci: etnografi virtual, Instagram, perundungan siber.

\section{PENDAHULUAN}

Perkembangan perangkat teknologi dan informasi membuat seseorang lebih mudah mengakses dunia virtual. Dalam era media baru, manusia diberikan banyak pilihan untuk mengakses media siber yang dibutuhkan, tergantung dengan fungsi atau kegunaan yang difasilitasi oleh media siber itu sendiri. Keberadaan media sosial sebagai jejaring sosial di dunia virtual merupakan salah satu jenis media siber. Dengan media sosial, setiap pengguna memiliki kebebasan untuk memproduksi informasi demi kepentingankepentingan yang mereka maksudkan. Selain itu, tanpa hambatan ruang dan waktu, 
pengguna media sosial juga dapat tersimpul dan terhimpun dalam satu jaringan besar sehingga siapa saja bisa terhubung. Melalui media sosial, warganet dapat terhubung dengan komunitas global. Mereka dapat membagikan ide dan gagasan yang mereka miliki, warganet juga dapat bertukar pengetahuan dan budaya, serta dapat berkolaborasi dalam projek apa pun yang mereka senangi dan butuhkan. Dalam hal yang lebih sederhana, melalui media sosial, warganet dapat berbagi informasi mengenai kehidupan kesehariannya, berbagi gambar dan video mengenai aktivitas terbaru yang sedang mereka kerjakan, bahkan melalui media sosial manusia dapat berbagi pandangan politik.

Namun akhir-akhir ini praktik interaksi antar pengguna media sosial seringkali memunculkan banyak persoalan dengan maraknya perundungan siber yang terjadi di antara pengguna. Menurut Ketua Umum Gerakan Nasional Literasi Digital \#Siberkreasi yang dilansir dari halaman inet.detik.com yang diakses pada tanggal 10 September 2018, Dedy Permadi mengatakan bahwa hal ini disebabkan oleh posisi Indonesia di antara anggota G20 yang masih rendah (Haryanto, 2018). Sedangkan jarak antara pembangunan infrastruktur teknologi dengan literasi digital sangat tinggi. Dengan minimnya kemampuan literasi digital dalam memahami konten digital, masyarakat Indonesia belum mampu berpikir secara kritis dan ilmiah saat mendapatkan sebuah informasi dari media sosial (Haryanto, 2018). Alhasil banyak di antara masyarakat yang menelan mentah-mentah informasi bohong atau hoaks dan menyebarkannya kembali tanpa memverifikasi kebenaran data dari informasi tersebut. Karena sikap yang tidak terbiasa dalam memverifikasi informasi yang diterima, banyak di antara warganet Indonesia yang mudah sekali tersulut oleh konten yang memuat provokasi terhadap isu tertentu dan langsung memberikan umpan balik negatif di kolom komentar yang disediakan, tanpa berpikir panjang apakah umpan balik tersebut memiliki efek buruk bagi pemilik informasi atau warganet lainnya. Sehingga dari fenomena ini, muncullah berbagai macam kasus perundungan siber yang merugikan banyak pihak.

Perundungan siber merupakan istilah yang dikenal sebagai tindakan penghinaan, kekerasan psikis, atau intimidasi yang dilakukan seseorang, kelompok, atau institusi melalui perangkat teknologi dan informasi di media siber kepada orang, kelompok, atau institusi lain. Tindakan tersebut dimaksudkan untuk mempermalukan, mengintimidasi, menyebar keburukan dan kebencian di media siber, baik ditunjukkan secara khusus kepada korban maupun dengan cara diketahui publik (Nasrullah, 2015). Meskipun negara Indonesia memiliki Undang-Undang No. 11 Tahun 2009 tentang Informasi dan Transaksi Elektronik (UU ITE) yang mengatur sanksi pidana untuk para pelaku perundungan/penghinaan, hal ini tidak serta merta menghentikan para pelaku perundungan menggencarkan aksinya di media sosial. Pelaku perundungan siber berpikir bahwa tindakan yang dilakukan tanpa empati dan apa yang dilakukan tidak berdampak besar bagi korban. Lebih lagi dunia siber memberikan kesempatan relatif mudah bagi pelaku untuk sengaja menyakiti korban dan pada akhirnya memungkinkan terjadi intimidasi tanpa dibatasi ruang dan waktu. Padahal dampak yang ditimbulkan dari perundungan siber ini sangat serius. Korban dapat mengalami tingkat depresi yang lebih tinggi dibandingkan kekerasan verbal lainnya, dan memunculkan keinginan bunuh diri yang tinggi yang biasa dikenal dengan cyberbullicied (Rastati, 2016).

Perundungan siber juga diperparah dengan fasilitas anonimitas dan pseudonimitas yang mereka dapatkan dari sistem di media sosial. Menurut Shariff dan Hoff (2007), "cyberbullying is especially insidious because of its anonymous nature", perundungan siber sangat berbahaya karena sifat anonimnya. Anonimitas berfungsi melindungi seseorang dari serangan dan ancaman juga menjauhkan seseorang dari akuntabilitas dengan seluruh tanggung jawab apa yang dikatakan. Sedangkan pseudonimitas memungkinkan seseorang untuk menambahkan kesan akan citranya. Pseudonimitas satu tingkat lebih tinggi di atas anonimitas. Individu mengonstruksi identitas 
melalui nama samaran, foto semu yang dapat dirujuk pada tokoh-tokoh kartun, tokoh idola, karikatur, lukisan dan data grafis lainnya yang tidak relevan dengan identitas sesungguhnya (Fardiah, 2011). Dengan maraknya kasus perundungan siber tersebut, beberapa institusi maupun publik figur mulai angkat bicara mengenai isu ini, salah satunya
Gita Savitri. Gita Savitri atau yang akrab dikenal dengan panggilan Gitasav merupakan selebgram dan YouTuber yang sudah aktif berbicara mengenai ujaran kebencian (hate speech) dan pelecehan seksual (sexual harassment) di media sosial sejak tahun 2017.

Tabel 1

Pembahasan Isu Perundungan Siber

\begin{tabular}{|c|c|c|c|}
\hline \multicolumn{4}{|c|}{ Track Record Pembahasan Isu Perundungan Siber oleh Gita Savitri } \\
\hline No & Topik Pembahasan & Tanggal Publikasi & Media Publikas \\
\hline 1 & $\begin{array}{l}\text { Life Update + Ngobrol Tentang Hatespeech } \\
\text { Beropini episode } 13\end{array}$ & 13 Agustus 2017 & YouTube \\
\hline 2 & Bertutur Kata di Era Digital & 10 September 2017 & Blogspot \\
\hline 3 & Creator For Change : The Hate You Give & 28 September 2017 & YouTube \\
\hline 4 & Yang Penting Buat Diomongin | Beropini episode 26 & 29 Mei 2018 & YouTube \\
\hline 5 & Akun@warganetbersabda dibuat & 27 Agustus 2018 & Instagram \\
\hline 6 & $\begin{array}{l}\text { Pelecehan Seksual dan Rape Culture Disekitar Kita } \\
\text { Pagi-pagi episode } 2\end{array}$ & 30 September 2018 & YouTube \\
\hline 7 & Some Informations We All Need & 30 September 2018 & Blogspot \\
\hline 8 & $\begin{array}{l}\text { Narasumber Deutsche Welle Women Talk Online } \\
\text { mengenai Cyber Violence }\end{array}$ & 25 November 2018 & Facebook \\
\hline
\end{tabular}

Sumber: Olahan Peneliti (2019)

Selain aktif menyuarakan opininya terhadap isu-isu tersebut, Gita Savitri juga terpilih menjadi salah satu perwakilan pertama Indonesia untuk program Creators for Change yang diadakan oleh Google dan VICE Media di London. Program tersebut membiayai Gita Savitri dalam pembuatan video yang ditujukan untuk memerangi masalah sosial yang terjadi di masyarakat Indonesia. Setelah mengikuti Social Impact Camp selama dua hari di YouTube Space London, ia membuat dua buah video yang berjudul Berdampingan (Coexist) dan The Hate You Give sebagai bentuk tindak lanjut dari video project yang sedang diamanahkan kepadanya.

Meskipun Gita Savitri sudah sering menyuarakan persoalan mengenai perundungan siber dan memiliki banyak peran di dunia siber, hal ini tidak menjadikan Gita Savitri kebal konflik. Ia juga pernah tertimpa perundungan siber di platform-platform yang ia geluti salah satunya di Twitter dan Instagram. Hal tersebut terjadi karena ia mengekspos salah satu pelaku pelecehan seksual verbal yang menyerangnya di direct message Instagram dan ternyata akun tersebut merupakan akun palsu yang menggunakan nama orang lain. Dan orang yang dipakai namanya, menggugat Gita Savitri karena ia beranggapan kariernya akan hancur karena nama baiknya sudah tercemar.

Empat bulan setelah kasus tersebut mereda, Gita Savitri membuat sebuah akun bernama@warganetbersabda. Akun Instagram@ @warganetbersabda ini dipubliskan pada tanggal 27 Agustus 2018. Hingga tanggal 04 Oktober 2018 posting tersebut sudah mengunggah sebanyak 45 post dan 15 ribu pengikut.

Akun Instagram @warganetbersabda merupakan akun pertama yang melakukan perlawanan kepada para pelaku perundungan siber dan akun ini dikelola langsung oleh influncer muslim perempuan, Gita Savitri. Akun Instagram @warganetbersabda juga hidup dengan ramainya interaksi antara admin, yakni Gita Savitri sendiri dengan pengguna Instagram atau antar pengguna Instagram lainnya yang memiliki pandangan pro dan kontra di kolom komentar. Gita Savitri juga aktif merespons pernyataan atau pertanyaan pengikutnya dan kerap kali dari postingan pengikutnya tersebut ia jadikan postingan 
baru di akun Instagram @warganetbersabda tersebut. Oleh karena itu penelitian ini, berupaya untuk menjelaskan bagaimana pola interaksi virtual yang terjadi di akun Instagram@warganetbersabda yang membahas tentang perundungan siber.

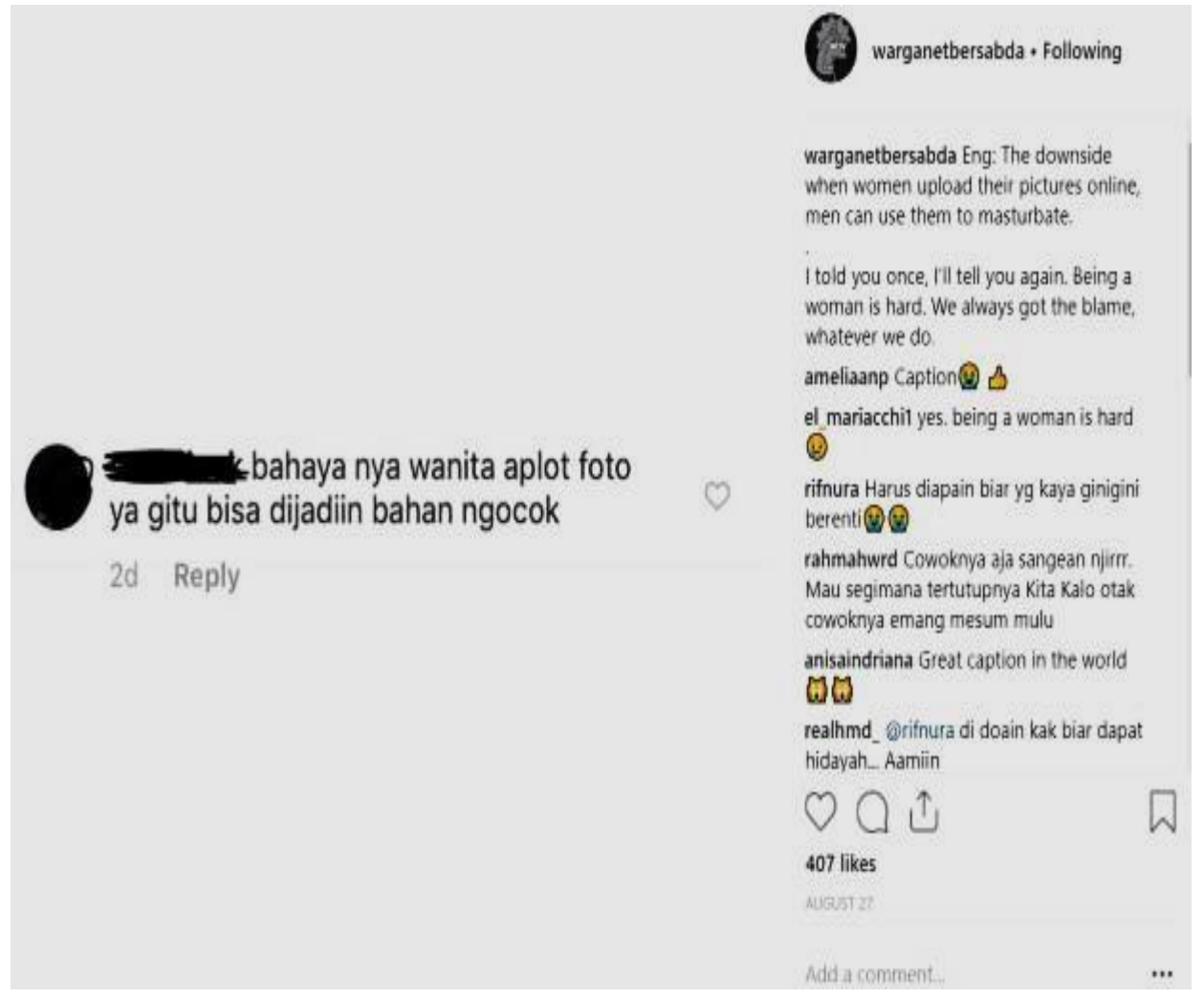

Sumber: Gita Savitri Instagram, 2018

Gambar 1. Cuplikan postingan 'sexual harrashment' akun@warganetbersabda

Pola interaksi virtual merupakan suatu pola yang menjelaskan tentang proses penyampaian dan penerimaan pesan yang bersifat interaktif yang terjadi di ruang maya atau dunia virtual. Dengan mengetahui pola interaksi virtual, masyarakat digital dapat mempelajari bagaimana pola ini bekerja dalam suatu fenomena digital sehingga masyarakat digital dapat mengadaptasi pola tersebut untuk mengelola dan mengembangkan gerakan yang sedang dikelola di media sosial. Oleh sebab itu mengetahui pola interaksi virtual menjadi penting karena di era media baru ini manusia dapat memanfaatkan penggunaan teknologi komunikasi sebagai kekuatan baru yang dapat menciptakan sebuah gerakan dan perubahan yang masif. New power atau kekuatan baru adalah kekuatan yang bersifat terbuka, partisipatif dan digerakkan oleh sesama. Kekuatan baru diunggah dan didistribusikan. Tujuan kekuatan baru bukan untuk menimbun kekuatannya melainkan untuk menyalurkannya (Timss \& Heiman, 2018).

Berdasarkan hal di atas, maka penulis menggunakan Teori Konvergensi Simbolik untuk menjelaskan bagaimana pola interaksi virtual terjadi di akun Instagram @ warganetbersabda. Karena teori ini berusaha untuk menerangkan bagaimana orang-orang secara kolektif membangun kesadaran simbolik melalui proses pertukaran pesan.

\section{LANDASAN KONSEP}

Penelitian terdahulu pernah dilakukan (Akbar MA \& Prahastiwi Utari, 2015) tentang cyberbullying pada media sosial Facebook dengan menggunakan metode analisis isi. Akbar melakukan pengamatan terhadap contoh pengalaman penindasan maya dari empat individu yang telah menjadi korban cyber melalui Facebook. Hasil analisis menunjukkan bahwa perilaku 
cyberbullying benar-benar terjadi di kalangan remaja. Menurut analisis Akbar, ciri-ciri dari penindas cyber adalah seseorang yang agresif dan intimidasi dan mengincar korban yang pasif. Berdasarkan analisis, jenis pesan penindasan maya terdiri dari nama-nama yang negatif, opini yang dibanting, ancaman bahaya fisik, dan pendapat yang meremehkan korban.

Selain itu, penelitian Juditha (2015) membicarakan tentang pola komunikasi cybercrime. Hasil penelitian menunjukkan faktor sumber pesan (scammers) memiliki kontrol yang besar terhadap diri sendiri dan berada dalam pengaturan komunikasi dengan korban-korbannya yang sama sekali tidak tahu siapa sebenarnya mereka. Scammers umumnya mencoba menyampaikan unsur-unsur diri yang terbaik, termasuk kepribadian, prestasi, dan bahkan penampilan (foto) melalui saluran komunikasi internet. Penerima pesan (korban) yang sedang kesepian dan mencari jodoh biasanya langsung tersanjung dengan pesan cinta dan tanpa pikir panjang melakukan umpan balik. Komunikasi secara intens pun terjalin hingga korban terjerumus dan masuk perangkap penipuan dan kehilangan uang hingga ratusan juta rupiah.

Penelitian serupa juga dilakukan oleh Hassan dkk. (2018) tentang kasus selebritas yang mengalami cyberbullying. Hasil penelitian menunjukkan bahwa pengamat (bystanders) memilih untuk campur tangan berdasarkan hubungan mereka dengan selebriti dan hasil dari perilaku prososial mereka. Sementara itu, efek pengamat yang tidak memiliki informasi, tingkat hubungan dengan para selebriti yang rendah dan tidak melihat adanya keparahan perundungan pada korban adalah di antara alasan mengapa mereka tidak ingin campur tangan. Temuan awal dapat memberikan beberapa wawasan tentangbagaimana cara untuk mendorong pengamat (bystanders )agar mengambil tindakan positif untuk menghentikan cyberbullying.

Penelitian selanjutnya Halder dan Jaihankar (2011) menjelaskan tentang cyber socializing, pertumbuhan kejahatan hi-tech yang menargetkan anggota perempuan melalui social networking websites (SNWs), kebutuhan untuk mengonseptualisasikan pelanggaran, tipologi dan pola viktimisasi perempuan yang menggunakan SNWs, emosional serta faktor resiko fisik perempuan yang menggunakan SNWs, menyusun alasan-alasan bagi korban perempuan yang menggunakan SNWs dan pertumbuhan korban. Internet memberikan kesempatan bebas kepada perempuan untuk menyuarakan pendapatnya dan ekspresinya. Tapi, internet yang bebas ini juga membuka kesempatan untuk kejahatan siber seperti cyber flame, cyber hate speech and cyber bullying. cyber crime itu nyata adanya dan terus tumbuh melalui social networking websites, e-mail, online chat rooms, SNWs, dll. Alasan dan motif para pelaku melakukan pelecehan kepada korban karena masalah emosional. Selain itu juga karena pelaku berlindung pada identitas yang dikamuflase. Lebih lagi, hukum yang berlaku juga masih belum memadai. Dua alasan utama untuk pertumbuhan korban online wanita pada SNWs adalah ketiadaan hukum siber universal sensitif gender yang tepat dan kurangnya kesadaran akan mode keamanan di antara pengguna.

Perbedaan dengan penelitian ini adalah mengamati interaksi yang sudah terjadi antara admin Gita Savitri (selebgram yang pernah menjadi korban lalu mengangkat isu perundungan siber dengan menciptakan komunitas baru yaitu akun Instagram @warganetbersabda) dengan pengamat (bystanders) bahkan pengikutnya.

\section{Teori Konvergensi Simbolik}

$\begin{array}{rrr}\text { Menurut Bormann } & \text { dalam } & \text { Suryadi } \\ \text { (2010) menyatakan bahwa teori }\end{array}$ Konvergensi Simbolik dibangun dalam kerangka paradigma naratif yang meyakini bahwa manusia merupakan Homo Narrans, yakni makhluk yang saling bertukar cerita atau narasi yang menggambarkan pengalaman dan realitas sosialnya. Teori ini berusaha menerangkan bagaimana orangorang secara kolektif membangun kesadaran simbolik bersama melalui proses pertukaran pesan. Kesadaran simbolik yang terbangun dalam proses tersebut kemudian menyediakan semacam makna, emosi dan motif untuk bertindak bagi orang-orang atau 
kumpulan orang yang terlibat di dalamnya. Sekumpulan individu ini dapat berasal dari kelompok orang yang telah saling mengenal dan berinteraksi dalam waktu yang relatif lama. Bisa juga bersumber dari orang-orang yang tidak saling mengenal dan memiliki cara berbeda dalam menafsirkan lambang yang digunakan, tapi mereka kemudian saling berkomunikasi sehingga terjadi konvergensi, yang pada gilirannya menciptakan realitas simbolik bersama. Dengan demikian, proses konvergensi dapat muncul bukan hanya dalam kelompok kecil yang relatif saling mengenal tetapi bisa juga terjadi pada rapat akbar, atau suatu saat seseorang mendengarkan ceramah, atau ketika menikmati film dan iklan politik di televisi.

Teori konvergensi simbolik menurut Bormann (1985) memiliki tiga bagian struktur. Bagian pertama berkaitan dengan penemuan dan pengaturan bentuk serta pola komunikasi berulang yang menunjukkan adanya evolusi dan kehadiran dari kesadaran kelompok. Bagian kedua terdiri dari deskripsi kecenderungan dinamis dalam sistem komunikasi yang menjelaskan mengapa kesadaran kelompok muncul, berlanjut, menurun, dan menghilang, serta efek-efek seperti kesadaran kelompok yang memiliki makna, motif dan komunikasi dalam kelompok. Bagian ketiga dari teori ini terdiri dari faktor-faktor yang menjelaskan mengapa orang berbagi fantasi.

Di samping itu terdapat dua asumsi pokok yang menjadi dasar Teori Konvergensi Simbolik. Asumsi pertama adalah realitas diciptakan melalui komunikasi. Dalam hal ini, komunikasi menciptakan realitas dengan mengaitkan antara kata-kata yang digunakan dengan pengalaman atau pengetahuan yang diperoleh. Asumsi kedua, makna individual yang terhadap simbol dapat mengalami konvergensi (penyatuan) sehingga menjadi realitas bersama. Realitas dalam teori ini dipandang sebagai susunan narasi atau cerita-cerita yang menerangkan bagaimana sesuatu harus dipercayai oleh orang-orang yang terlibat di dalamnya. Bormann menyebutkan bahwa metode untuk mengoperasionalkan teorinya dikenal dengan istilah fantasy theme analysis (analisis tema fantasi).

\section{METODE PENELITIAN}

Penelitian ini menggunakan paradigma riset kualitatif konstruktivisme dengan pendekatan etnografi virtual. Objek penelitian ini adalah akun Instagram @ warganetbersabda. Sedangkan subjek penelitian ini adalah Gita Savitri Devi seorang selebgram dan youtuber yang membuat dan mengelola akun Instagram @ warganetbersabda. Pengumpulan data dari sumber data primer dilakukan melalui observasi, wawancara dan dokumentasi. Dalam penelitian ini, peneliti melakukan observasi partisipan dengan menjadi pengguna internet dan pengikut akun Instagram @warganetbersabda sehingga peneliti dapat melakukan pengamatan dari dalam dan dari luar komunitas. Observasi dilakukan untuk melihat pola interaksi virtual yang dilakukan oleh Gita Savitri selaku admin dengan pengikutnya dan pola interaksi virtual yang dilakukan antar pengikutnya. Sedangkan proses wawancara dilakukan untuk mendapatkan pernyataan langsung dari Gita Savitri selaku admin dalam mengelola akun Instagram @warganetbersabda dan pernyataan dari pengikutnya mengenai alasan dan bagaimana interaksi yang dilakukan oleh pengikutnya terjadi di akun Instagram @ warganetbersabda. Peneliti melakukan wawancara tatap muka (face to face) dan menggunakan medium e-mail serta aplikasi instant messaging dalam melakukan penelitian ini.

\section{HASIL PENELITIAN DAN PEMBAHASAN}

Borman (1990) menjelaskan teori konvergensi simbolik sebagai percakapan yang memunculkan simbol / fantasi yang ditanggapi oleh kelompok-kelompok lain, sehingga penerima dan pemberi pesan satu sama lain mengerti maksud pesan yang disampaikan. Tema fantasi sebagai isi pesan 
yang didramatisasi oleh Gita Savitri telah menciptakan rantai fantasi. Borman mengartikan rantai fantasi sebagai serangkaian ide yang para anggotanya tergabung bersama seperti sebuah fantasi. Gita Savitri membuat akun @warganetbersabda dengan konten-konten tentang perundungan siber. Rantai fantasi yang sudah terbentuk akan menciptakan konvergensi simbolik dan landasan penyatuan makna bersama para follower @warganetbersabda. Bormann (1985) membangun teori konvergensi simbolik melalui paradigma naratif yang meyakini bahwa manusia merupakan Homo Narrans yaitu makhluk yang saling bertukar cerita. Sedangkan istilah simbolik itu sendiri terkait dengan kecenderungan manusia untuk memberikan penafsiran dan menanamkan makna kepada berbagai lambang, tanda, kejadian yang tengah dialami, atau bahkan tindakan yang dilakukan manusia (Bormann, 1985). Bormann mengartikan manusia sebagai pengguna simbol. Dalam akun @warganetbersabda tersebut, follower yang tergabung saling berinteraksi dan menghasilkan simbol bersama dan kemudian terciptanya kesadaran bersama tentang hal yang diperbincangkan.

Pada tanggal 27 Agustus 2018, Gita Savitri mengumumkan melalui akun Instagram pribadinya bahwa ia telah membuat akun Instagram kedua yang mengakurasi komentar-komentar bernada ujaran kebencian dan pelecehan seksual secara verbal diterima melalui internet. Akun kedua tersebut oleh Gita Savitri diberi username@warganetbersabda. Akun Instagram @warganetbersabda sendiri terdiri dari cuplikan gambar yang berasal dari pesan-pesan yang dilayangkan kepada Gita Savitri secara langsung melalu direct message Instagram @ gitasav dan komentarkomentar yang didapat dari kolom komentar akun media sosial pribadinya.

"Saya membuat proyek kecil, proyek tersebut adalah akun Instagram kedua yang saya gunakan, bernama @ warganetbersabda. Disana ada semua tangkapan layar dari direct message, komentar-komentar yang saya dapatkan dari orang-orang aneh di internet." (Wawancara Gita Savitri 25 November 2018)

$\begin{array}{ccr}\text { Kehadiran } & \text { akun } & \text { Instagram } \\ \text { @ warganetbersabda } & \text { menuai } & \text { banyak }\end{array}$ kontroversi. Meski begitu, Gita Savitri tetap mempertahankan akun tersebut dengan terus menjelaskan kepada warganet alasan Gita Savitri membuat akun tersebut. Cara yang Gita Savitri lakukan untuk menjelaskan hal tersebut adalah dengan menuliskan penjelasan di caption beberapa postingan ataupun saat membalas komentar di kolom komentar akun Instagram @warganetbersabda. Gita Savitri sering kali mendapatkan komentar-komentar yang mengandung unsur perundungan siber. Gita Savitri dikenal sebagai perempuan yang lantang menyuarakan opininya terhadap isuisu yang sedang hangat di tengah masyarakat Indonesia maupun dunia. Gita Savitri menyuarakan opini tersebut melalui video yang ia unggah di segmen beropini kanal YouTube pribadinya. Karena keberaniannya untuk bersuara terhadap isuisu tersebut, Gita Savitri tidak hanya mendapat respons positif dari penontonnya, sering kali Gita Savitri juga mendapat respons negatif dari warganet yang tidak memiliki satu pandangan dengan opininya. Sering kali warganet juga berkomentar mengenai hal yang sama sekali tidak ada kaitannya dengan pembahasan yang telah Gita Savitri bahas di videonya. Saking derasnya mendapatkan perundungan siber, Gita Savitri kerap menangkap (capture) komentar-komentar tersebut di ponselnya. Sebelumnya Gita Savitri juga pernah mendapatkan banyak komentar negatif dari warganet Indonesia di Instagram maupun di Twitter karena ia mengekspos salah satu pelaku pelecehan seksual verbal yang menyerangnya di direct message Instagram dan ternyata akun tersebut merupakan akun palsu yang menggunakan nama orang lain. Orang yang dipakai namanya, menggugat Gita Savitri karena ia beranggapan kariernya akan hancur karena nama baiknya sudah tercemar. Kronologi cerita ini, Gita Savitri ceritakan dalam wawancaranya,

"Beberapa bulan yang lalu, saya mendapat pesan langsung. Dan orang ini mengatakan kepada saya agar saya menjadi 
pelacur, menjadi lonte. Saya sebenarnya juru bicara salah satu merek make up terbesar di Indonesia. Orang ini berkata bahwa saya hanya membuang-buang uang perusahaan ini. Saya mendapat pelecehan seksual dari seseorang yang menggunakan identitas palsu. Saya mengekspos gambar akun ini. Ternyata, ada seorang pria di luar sana yang bertanya kepada saya melalui pesan langsung yang mana sebenarnya saya tidak tahu, saya diminta untuk menarik gambar akun tersebut, yang sebenarnya sudah saya lakukan setelah salah satu pengikut saya mengatakan bahwa orang ini adalah juniornya di universitas. Dia tahu orang itu dan tidak mungkin orang ini mengatakan hal yang mengerikan kepada saya. Jadi setelah saya tahu itu, saya langsung menarik gambarnya tetapi orang yang memiliki identitas ini bilang, "Apa yang kamu lakukan? Itu bisa merusak reputasi saya, bisa menghancurkan hidup saya, bisa membuat saya kehilangan pekerjaan." (Wawancara Gita Savitri 25 November 2018)

Setelah pemilik akun ini menggugat Gita Savitri, pemilik akun mengekspos seluruh percakapannya dengan Gita Savitri yang dilakukan via direct message Instagram ke InstaStory miliknya, sehingga banyak warganet yang mengetahui seluruh isi percakapan antara Gita Savitri dengan si penggugat. Dari sanalah tanggapan warganet kepada Gita Savitri bermunculan. Banyak warganet yang memprotes cara Gita Savitri menanggapi si penggugat. Tanggapan warganet ini menyebar hingga menjadi buah bibir warganet Twitter dan Instagram Indonesia. saat itu. Gita Savitri menuturkan dalam wawancaranya bahwa sejak saat itu, banyak warganet yang merundung dirinya dengan kalimat-kalimat kebencian. Dan ia dengan suaminya berusaha untuk memblokir dan menghapus komentar-komentar tersebut.

"Akhirnya saya mendapatkan perundungan oleh ribuan orang di internet. Saya menjadi trending topic di Twitter Indonesia. Banyak orang membicarakan saya. Begitu banyak orang yang memelintir keseluruhan cerita. Selama lima hari, suami saya dan saya berusaha memblokir dan menghapus semua komentar kebencian. Saya mendapat begitu banyak pesan langsung, itu benar-benar mengerikan." (Wawancara Gita Savitri 25 November 2018)

Setelah kejadian tersebut mereda, Gita Savitri tergerak untuk membagikan gambargambar perundungan siber yang telah ia dapat di media sosial kepada khalayak umum, khususnya pengguna Instagram. Karena hal itu, terbentuklah akun Instagram @ warganetbersabda.

"Biasanya jika saya mendapatkan komentar aneh-aneh, komentar tersebut saya screen capture dan simpan di telefon genggam. Suatu hari saya merasa penting untuk menunjukan koleksi yang saya miliki kepada orang di luar sana untuk menunjukkan ke khalayak umum bahwa publik figur mendapatkan harassment dan hate on "daily" basis." (Wawancara Gita Savitri 7 Desember 2018)

Ia menuturkan dalam wawancara bersama peneliti bahwa akun Instagram @ warganetbersabda merupakan sarana ia untuk melawan karena kehidupannya telah diganggu. Dan ia berhak untuk melakukan hal tersebut.

"Saya ingin menunjukkan apa yang sering saya alami dan sebagai manusia saya berhak untuk speak out jika saya merasa hidup saya diganggu." (Wawancara Gita Savitri 7 Desember 2018)

Gita Savitri pernah menjadi korban perundungan siber, ia juga terus menegaskan di dalam caption ataupun komentar di akun Instagram @warganetbersabda, bahwa ia membuat akun ini ditujukan untuk mendorong para korban perundungan siber agar mau berani berbicara. Karena menurutnya, selama ini, korban perundungan siber dipaksa diam dan pasrah.

"Selama ini para korban bully dan harassment disuruh diam, disuruh mendoakan aja pelakunya, disuruh pasrah." (Penuturan Gita Savitri tanggal 29 Agustus 2018)

Dalam wawancaranya, Gita Savitri berpendapat bahwa, akun Instagram @ warganetbersabda tidak hanya ditujukan untuk korban perempuan. Karena 
perundungan siber bisa dialami oleh siapa pun tanpa memandang gender.

"Saya pikir ini (akun Instagram @warganetbersabda) tidak hanya untuk wanita tetapi untuk kita semua. Kita semua harus membela diri kita sendiri. Beberapa orang mungkin tidak menyukainya, beberapa orang mungkin melihatnya kita yang terlalu sensitif" (Wawancara Gita Savitri 25 November 2018). Ucapan ini, ia tunjukan dengan memposting perundungan siber yang didapatkan Jojo dan Pandji di media sosial.

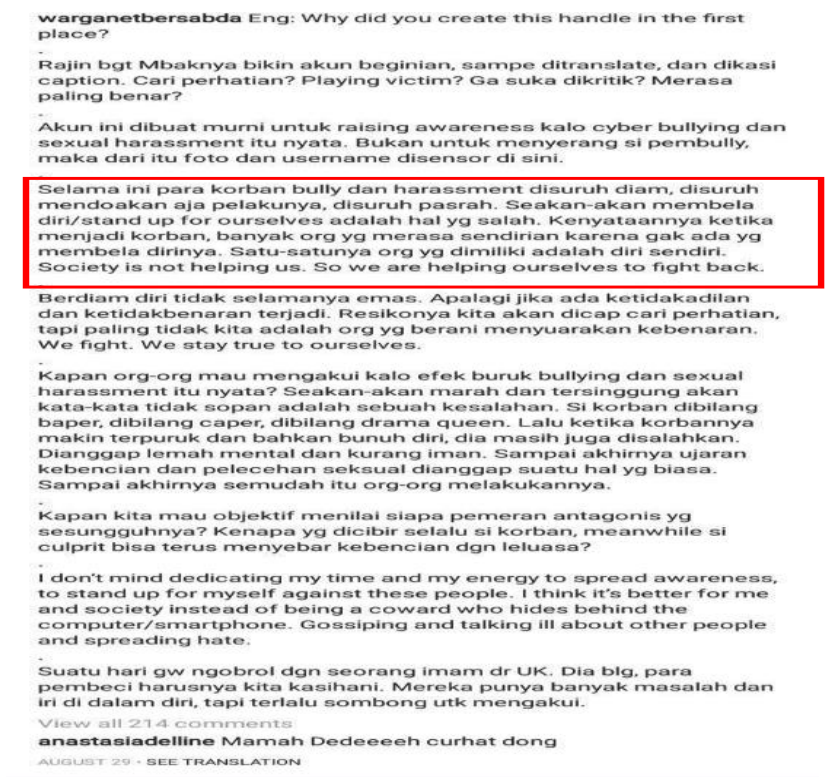

Sumber: https://www.Instagram.com/warganetbersabda

Gambar 2. Caption Akun Instagram @warganetbersabda
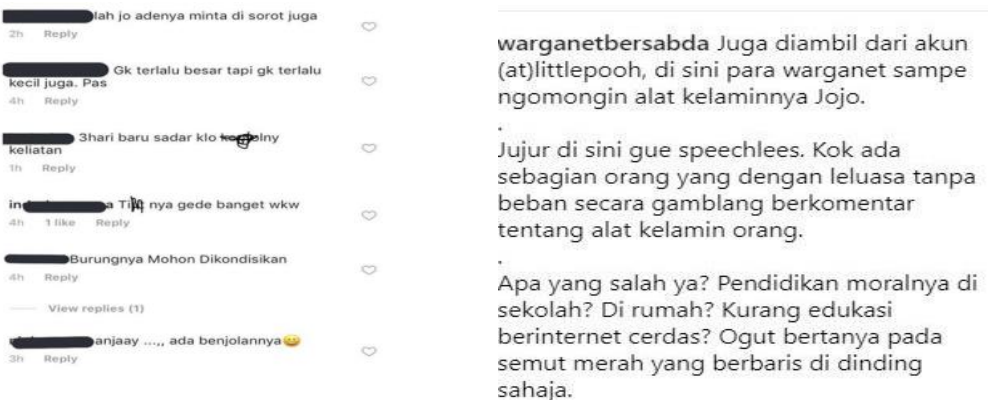

Sumber: https://www.Instagram.com/warganetbersabda

Gambar 3. Postingan Perundungan Siber Jojo
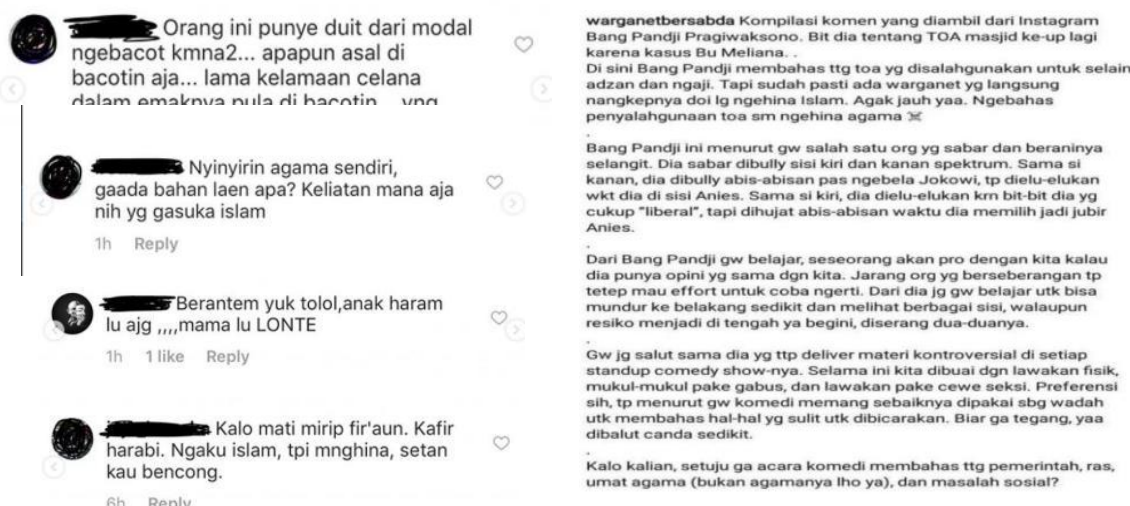

Sumber: https://www.Instagram.com/warganetbersabda

Gambar 4. Postingan Perundungan Siber Pandji Pagiwaksono 
Gita Savitri berprinsip bahwa yang harus dilakukan oleh para korban perundungan siber adalah angkat suara meskipun keadaannya tidak mendukung. Melalui tindakannya mengunggah komentar-komentar kebencian yang ia dapat, ia berusaha menunjukkan kepada para korban bahwa ia berani untuk menjadi pionir dalam melawan para pelaku perundungan siber. Hasil penelitian menunjukkan bahwa akun Instagram @ warganetbersabda memiliki pola interaksi virtual yaitu Gita Savitri selaku admin secara konsisten mengunggah cuplikan gambar (screenshot) komentar dengan menyensor nama pelaku serta foto profil akun Instagram pelaku. Selain menampilkan keaslian dari bukti dokumentasi, menyensor nama pelaku dapat menjaga privasi, keamanan dan juga kefokusan pembaca terhadap isi konten. Menyensor nama dan foto profil pelaku juga dapat memutus siklus perundungan siber berulang yang dapat terjadi antar pengguna. Gita Savitri selaku admin juga membuat caption yang variatif. Jenis caption yang Gita Savitri tulis sangat beragam. Diantaranya adalah menerjemahkan isi cuplikan gambar kedalam bahasa inggris, menanyakan pertanyaan sarkasme, menuliskan lirik lagu, melemparkan lelucon sarkasme, menulis tulisan renungan, menulis kalimat peringatan, saran dan emoji. Caption memberikan kesempatan untuk pembaca mengetahui sudut pandang admin dalam menanggapi kasus perundungan siber dan Gita Savitri memanfaatkan penggunaan caption untuk menginformasikan, mengedukasi dan menstimulus pembaca agar mau berdiskusi. Pola interaksi virtual akun Instagram @warganetbersabda juga selalu ditanggapi warganet dan pola interaksi Gita Savitri membentuk pola interaksi virtual yang masif. Dalam pola interaksi virtual, perlu bagi admin mendapatkan tanggapan dari pembaca yang diajak berdiskusi. Berikut screenshot dari pola interaksi virtual Gita Sav:

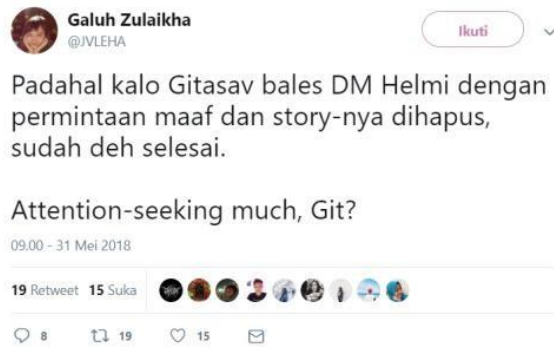

Sumber: https://twitter.com/JVLEHA/status/1002006941701419008

Gambar 5. Ujaran kebencian yang ditunjukkan untuk Gita Savitri

Meskipun Gita Savitri sudah sering menyuarakan persoalan mengenai perundungan siber dan memiliki banyak peran di dunia siber, hal ini tidak menjadikan Gita Savitri kebal konflik. Ia juga pernah tertimpa perundungan siber di platform-platform yang ia geluti salah satunya di Twitter dan Instagram. Respons admin akun Instagram @warganetbersabda dalam menanggapi pernyataan atau pertanyaan warganet juga dilakukan untuk menjaga tensi interaksi antara admin dengan pengikutnya dan antar pengikut akun Instagram @warganetbersabda agar bisa terus berkembang. Gita Savitri sebagai admin akun Instagram@warganetbersabda sendiri sering kali membalas komentarkomentar yang dilontarkan pengikutnya. Adapun komentar yang dibalas oleh Gita Savitri adalah komentar-komentar yang menurutnya perlu penjelasan lebih dari Gita Savitri. Apabila ia memiliki waktu luang, ia pun senantiasa membalas komentarkomentar pengikut tersebut tanpa alasan apa pun. Selain itu menurut pengakuannya, kadang kala ia juga membalas komentarkomentar yang tidak penting untuk dibalas. 
gabriellia_butarbutar Ka gitt 98 ? 9 semangat ya kak... Ya dari kakak aku semakin belajar gak semua orang menyukai kita dan itu lumrah... Tp aku masih bertanya, hati kakak ini terbuat dari apa ya kuat bgt... Coba aku :") aku pernah ngalami depresi gara2 mikir yang beginian... He he he.. Bagi tipsnya dong kak biar kita bisa strongg gituu

16w 1 like Reply

View previous replies (2)

7. warganetbersabda @gabriellia_butarbutar

please seek help! bahkan kalo menurut kamu perlu, seek professional help! ga ada yg salah dari itu. gather your family, friends. seek emotional support juga. jangan dipendam aja depresi kamu, suatu saat dia bisa muncul lagi dan muncul lagi. once muncul lagi, kamu bisa merespon ekstrim. penyakit apapun harus disembuhin completely

16w 8 likes Reply

Sumber: https://www.Instagram.com/warganetbersabda

Gambar 6. Komentar yang dibalas admin akun Instagram @ warganetbersabda

Adapun konsekuensi dari interaksi yang terlalu masif adalah sulitnya mengontrol kualitas komentar yang dilontarkan oleh warganet akun Instagram @warganetbersabda. Apabila hal tersebut terjadi, Gita Savitri sebagai admin akan menanggulanginya dengan cara bercakap privat melalui direct message Instagram.

Gita Savitri adalah seorang tokoh publik berpengaruh (influencer) yang memiliki serangkaian pengalaman tentang perundungan siber yang ia sampaikan secara naratif di akun Instagram @ warganetbersabda. $\quad$ Akun @warganetbersada merupakan akun instagram grup yang dikelola oleh Gita Savitri dengan suatu tujuan. Gita Savitri alami guna mengajak orang-orang agar mau berinteraksi di dalam akun Instagram @ warganetbersabda. Dalam tema fantasi ini, pesan yang didramatisasi bukanlah pesan yang memiliki muatan imajinatif, ataupun peristiwa yang terjadi saat ini. Melainkan membicarakan peristiwa yang telah terjadi di masa lampau atau yang akan terjadi di masa depan. Gita Savitri memiliki kemampuan retoris yang baik, yang mana ia mampu mendramatisasi tema fantasi yang ia peroleh dari caption pengalam perundungan siber yang dialami. Oleh karena itu, tema fantasi yang dibagikan oleh Gita Savitri merupakan dokumentasi komentar mengenai perundungan siber yang dialami langsung oleh Gita Savitri dan juga yang dialami beberapa publik figur Indonesia lainnya. Bentuk tema fantasi perundungan siber yang
Gita Savitri bagikan yaitu komentar-komentar warganet yang mengandung ujaran kebencian, pelecehan seksual secara verbal, name calling (saling mengata-ngatai), mempermalukan bagian tubuh, pencabulan siber, pengucilan, dan pencemaran nama baik. Gita Savitri mengemas tema fantasi berupa cerita perundungan siber tersebut dengan cara mendramatisasi pesan melalui unggahan cuplikan gambar komentar yang ditunjukkan kepada pengikutnya dengan tampilan apa adanya, tanpa mengubah tampilan dari komentar tersebut, kecuali menyensor nama dan foto profil akun Instagram pelaku perundungan siber. Selanjutnya, cara Gita Savitri mendramatisasi pesan mengenai isu perundungan siber ini adalah dengan cara merangkai sedemikian rupa cerita, permainan kata, penggunaan dua bahasa dan lelucon sarkasme yang dituangkan dalam sebuah caption di setiap konten yang ia unggah di akun Instagram @warganetbersabda.

\section{Rantai Fantasi dalam Akun Instagram @warganetbersabda}

Setelah tema-tema fantasi tersebut diunggah dan diberi makna melalui caption yang Gita Savitri buat, akun Instagram @ warganetbersabda ini kemudian mendapatkan respons dari pengguna Instagram. Ada yang hanya mengunjungi, mengikuti hingga memberikan tanggapan di akun tersebut. Gita Savitri juga menggunakan simbol-simbol yang sesuai untuk membentuk identitas akun Instagram @waragnetbersabda, agar pesan yang disampaikan Gita Savitri 
tidak kontradiktif.

Dalam proses interaksi yang terjadi di akun Instagram @warganetbersabda, terjadi proses komunikasi transaksional antara Gita Savitri dengan pengikut akun Instagram @ warganetbersabda dan interaksi sesama pengikut lainnya. Gita Savitri sebagai admin gencar melakukan pengiriman pesan secara terus menerus kepada pengikut akun Instagram @warganetbersabda dan pesan tersebut secara kooperatif diterima dan diberikan umpan balik oleh pengikut akun Instagram@warganetbersabda. Berikut adalah bentuk pengiriman pesan atas umpan balik Gita Savitri kepada pengikutnya:

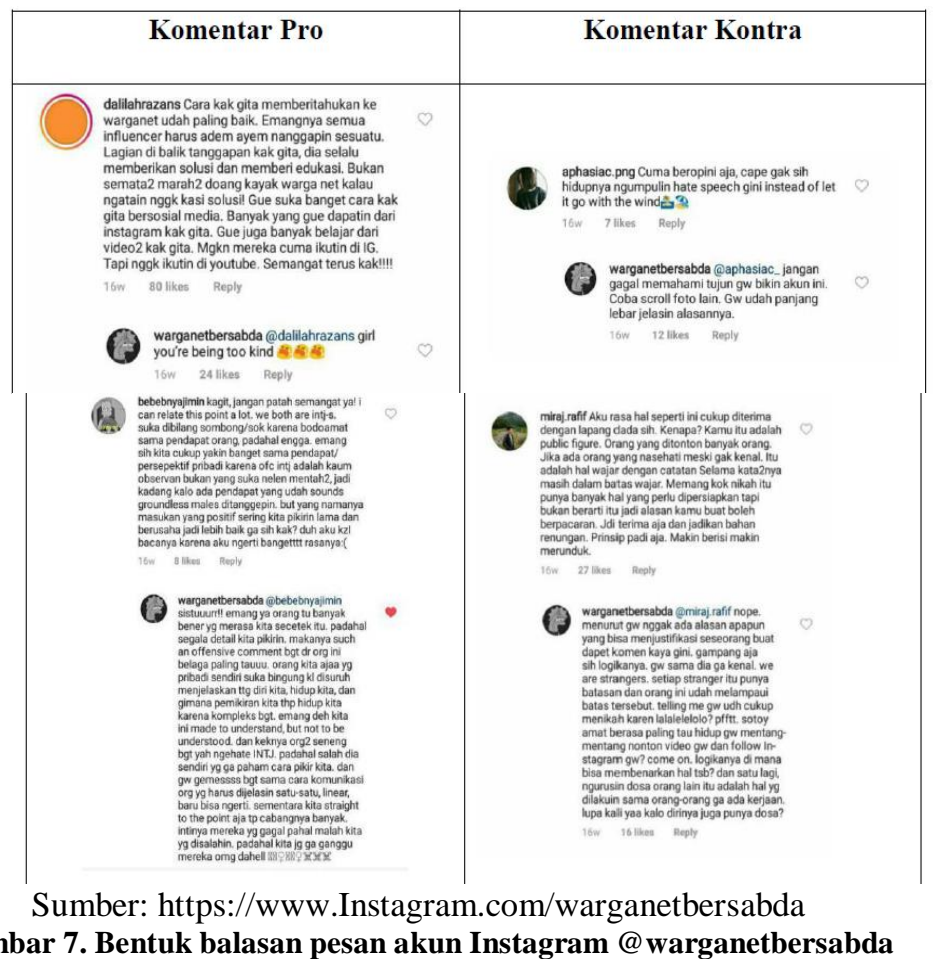

Dalam hal ini khalayak warganet yang berinteraksi di dalam akun Instagram @warganetbersabda pun dapat dikategorikan dalam dua tipologi, yakni sebagai pengunjung atau visitors dan penetap atau residents. Peneliti memiliki tiga informan (visitors dan residents) yang merupakan representasi warganet akun Instagram @ warganetbersabda. Informan pertama yaitu Fajriana Ramadhan mau mendedikasikan dan menghabiskan waktunya untuk melakukan interaksi sosial di akun Instagram @warganetbersabda. Fajriana tampak beberapa kali muncul untuk memberikan komentar, menanggapi komentar dari admin akun Instagram @warganetbersabda dan pengikut lainnya. Oleh karena itu, keberadaan Fajriana Ramadhan sudah banyak diketahui oleh pengguna lainnya dikarenakan frekuensi muncul Fajriana Ramadhan di kolom komentar terlihat dominan. Dalam hal ini, Fajriana Ramadhan disebut sebagai khalayak penetap (resident) akun Instagram @warganetbersabda. Informan selanjutnya Rosy Syahputri dan Nilna Faza merupakan pengguna Instagram yang hanya mengunjungi akun Instagram@warganetbersabda karena dilandasi minat mereka. Rosy Syahputri beberapa kali menyukai dan pernah berkomentar membagikan pengalamannya, namun tidak mengikuti akun tersebut. Nilna Faza hanya melihat-lihat konten dan membaca tanggapan warganet, tanpa ikut terlibat dalam diskusi yang sedang berlangsung. Rosy Syahputri dan Nilna Faza sekedar melihat, membaca satu dua isi konten yang dipublikasikan, namun tidak begitu banyak melakukan interaksi dan meninggalkan jejak pesan atau respons di sana. Sehingga mereka disebut sebagai pengunjung saja atau visitors. Adapun pengunjung dalam tipe ini juga dapat disebut sebagai lurkers atau pengintai. 
Fajriana Ramadhan memiliki kecenderungan kontra dengan sebagian kecil statement yang diunggah oleh Gita Savitri sehingga pola interaksi yang Fajrian Ramadhan lakukan adalah menyanggah opini Gita Savitri dalam beberapa postingan. Nilna Faza cenderung lebih terbuka dan suportif kepada apa yang telah diunggah di akun Instagram @warganetbersabda. Ia sesekali menyukai unggahan Gita Savitri dan mau menerima pandangan pengikut lainnya. Sedangkan Rosy Syahputri memiliki karakteristik sebagai warganet yang memiliki simpati dalam menanggapi kisah yang dibagikan oleh Gita Savitri. Sehingga Rosy Syahputri berkenan untuk turut membagikan kisah yang serupa dengan yang dialami oleh Gita Savitri.

Dalam hal ini karakteristik yang ada pada ketiga informan sebagai warganet telah menunjukkan dan memberikan gambaran mengenai pola interaksi yang terjadi di akun Instagram@warganetbersabda bahwa konvergensi simbolik telah terjadi dalam akun Instagram @warganetbersabda. Tema fantasi dan simbol yang Gita Savitri bagikan kemudian bertemu dengan warganet lainnya sehingga simbol-simbol tersebut saling bertemu, saling mendekati dan saling berimpitan. Sehingga hadirlah "meeting of mind" perjumpaan pikiran antara admin dengan pengikut dan pengikut dengan pengikut lainnya dalam akun Instagram @warganetbersabda.

Dengan adanya interaksi tersebut, maka terciptalah sebuah rantai fantasi di akun Instagram @warganetbersabda. Rantai fantasi ini meningkatkan tempo percakapan di akun tersebut dan memunculkan antusias para pengguna Instagram untuk ikut berpartisipasi dalam memberikan pandangannya.

\section{PENUTUP}

\section{Simpulan}

Pola interaksi virtual akun Instagram @warganetbersabda mengalami sebuah konvergensi yang mana konvergensi sebelumnya dibangun oleh Gita Savitri melalui dibagikannya tema fantasi berupa pengalamannya mendapat perundungan siber di media sosial dengan cara mengunggah cuplikan gambar bersensor dan menulis caption yang variatif secara berkala. Kemudian tema fantasi ini membentuk sebuah rantai fantasi yang melibatkan pengguna Instagram lainnya memberikan respons serta reaksi dari para followers @warganetbersabda yang telah dibagikan Gita Savitri.

Gita Savitri membuat caption yang variatif. Caption tersebut merupakan unggahan cuplikan gambar bersensor dari follower yang melakukan perundungan siber yang Gita Savitri ambil dari media sosial. Gita menampilkan keaslian dari bukti dokumentasi, menyensor nama pelaku dapat menjaga privasi dan menyensor nama pelaku dengan tujuan dapat memutus siklus perundungan siber. Caption dalam akun @warganetbersabda yang ditampilkan oleh Gita Savitri memberikan kesempatan untuk followers mengetahui sudut pandang Gita Savitri sebagai pemilik akun @ warganetbersabda dalam menanggapi kasus perundungan siber. Pola interaksi konten akun Instagram@warganetbersabda selalu ditanggapi warganet dan pola interaksi Gita Savitri membentuk pola komunikasi virtual yang masif. Dalam pola komunikasi virtual, perlu bagi admin mendapatkan tanggapan dari pembaca yang diajak berdiskusi. Adanya tanggapan warganet mengindikasikan bahwa akun Instagram @warganetbersabda memiliki interaksi yang dinamis, transaksional dan berjalan dua arah. Respons admin akun Instagram @warganetbersabda dalam menanggapi pernyataan atau pertanyaan warganet juga dilakukan untuk menjaga tensi interaksi antara admin dengan pengikutnya dan antar pengikut akun Instagram @ warganetbersabda agar bisa terus berkembang.

Gita Savitri mengemas tema fantasi berupa cerita perundungan siber tersebut dengan cara mendramatisasi pesan melalui unggahan cuplikan gambar komentar yang ditunjukkan kepada pengikutnya dengan tampilan apa adanya, tanpa mengubah tampilan dari komentar tersebut, kecuali menyensor nama dan foto profil akun Instagram pelaku perundungan siber. Selanjutnya, cara Gita Savitri mendramatisasi 
pesan mengenai isu perundungan siber ini adalah dengan cara merangkai sedemikian rupa cerita, permainan kata, penggunaan dua bahasa dan lelucon sarkasme yang dituangkan dalam sebuah caption di setiap konten yang Gita Savitri unggah di akun Instagram@warganetbersabda.

\section{Saran}

Dalam hal ini peneliti merekomendasikan kepada Gita Savitri selaku admin akun Instagram @warganetbersabda sebaiknya lebih memaksimalkan fitur tagar atau hastag dalam pembuatan caption. Hal ini dilakukan agar akun Instagram @warganetbersabda dapat menjangkau lebih banyak khalayak, mengingat caption akun Instagram $@$ waragnetbersabda sendiri sudah menggunakan dua bahasa, yakni bahasa Indonesia dan bahasa Inggris. Penggunaan tagar dapat mendukung dan menjembatani pembaca atau pengikut dari luar Indonesia untuk menemukan akun Instagram @warganetbersabda, sehingga hal tersebut dapat memudahkan mereka yang ingin membaca atau meneliti fenomena perundungan siber di Indonesia.

Selain itu peneliti juga menyarankan bahwa perundungan siber perlu ditindak lanjuti tidak hanya melalui jalur hukum, tapi perlu adanya usaha-usaha dialogis yang dilakukan dengan memanfaatkan teknologi terkini, salah satunya melalui pemanfaatan media sosial. Diharapkan kepada para selebgram, influencer ataupun tokoh masyarakat yang telah memiliki peran sebagai opinion leader di media sosial dapat menggunakan kesempatan tersebut dengan sebaik-baiknya untuk berinteraksi dengan para pengikutnya.

\section{DAFTAR PUSTAKA}

Akbar, M. A. (2015) Cyberbullying pada Media Sosial (Studi Analisis Isi tentang Cyberbullying pada Remaja di Facebook). Universitas Sebelas Maret.

Borman, E. G. (1990) Small Group Communication Theory: Theory And Practice. New York: Harpercollins.
Bormann, E. G. (1985) 'Symbolic Convergence Theory: A Communication Formulation', Journal Of Communication, 35(4), pp. $128-138$.

Fardiah, D. (2012) 'Interelasi Perempuan Dan Internet', Observasi, 10(1), hal 1-12.

Haryanto, A. T. (2018) Di Antara Anggota G20, Indonesia Minim Literasi Digital. Available at: $\quad$ https://inet.detik.com/Cyberlife/D3668529/Di-Antara-Anggota-G20-

Indonesia-Min Im-Litersi -Digital (Accessed: 10 September 2018).

Hassan, Syahida, Mohd Idzwan Yacob, T. N. dan S. Z. (2018) 'Should I Intervene: The Case Of Cyberbullying On Celebrities From The Perspective Of The Bystanders', in International Conference: Knowledge Management. Malaysia: Universiti Utara Malaysia.

Halder, Debarati dan K. Jaihankar. (2011) Cyber Criminology. USA: Taylor and Francis Group.

Hidayah, R. M. (3 Agutus 2018) Potret Perjalanan Gita Savitri. Available at: https://www.idntimes.com/Hype/Entertain ment/Rizna-M-Hidayah/Potret-PerjalananGita-Savitri-C1c2/full (Accessed: 20 March 2019).

Jaishankar, K. (2007) 'Cyber Criminology: Evolving a novel discipline with a new journal', International Journal. doi: 10.1016/j.ridd.2007.11.002.

Juditha, C. (2015) 'Pola Komunikasi Dalam Cybercrime (Kasus Love Scams)', Jurnal Penelitian dan Pengembangan Komunikasi dan Informatika, 6(2), hal 29-40.

Nasrullah, Rulli. (2015). Media Sosial Prosedur, Trend dan Etika. Bandung : Sembiosa Rekatama Media

Rastati, R. (2016) 'Bentuk Perundungan Siber Di Media Sosial Dan Pencegahannya Bagi Korban Dan Pelaku.', Jurnal Sosioteknologi, 15(2).

Shariff, S. dan D. L. H. (2007) 'Cyber Bullying: Clarifying Legal Boundaries For School Supervision In Cyberspace', International Journal of Cyber Criminology, 1(1).

Suryadi, I. (2010) 'Teori Konvergensi Simbolik', Jurnal Academica Universitas Tadulako, 2(2).

Timss, H. D. J. H. (2018) 'New Power: How Power Works In Our Hyperconnected World And How To Make It Work For You', in. New York: Doubleday. 